\title{
TÜRK DÜNYASINDA ORTAK İMLÂ (YAZIM) SORUNU*
}

Mehmet ÖZEREN**

\section{Özet}

Türk dünyasının dilde birlikteliği için ortak yazı dili ve alfabe yönünde birçok adım atılmıştır. Ancak bu çalışmalar ortak imlâ için yeterli olmamıştır. Günümüzde hem Kiril hem de Latin alfabesi kullanan çağdaş Türk lehçeleri, Rusça için belirlenmiş olan imlâ (yazım) kurallarını uygulamaktadırlar.

Bu çalışmada kısaca ortak alfabe oluşturma girişimleri üzerinde durulacak, daha sonra çağdaş Türk lehçelerinde yaygın olarak kullanılan Rusçanın imlâ (yazım) kurallarının oluşturulma sürecine değinilecektir. Ardından her başlık ve madde altında Türkiye Türkçesindeki, Rusçadaki ve diğer çağdaş Türk lehçelerindeki kullanımlar örneklerle verilecek ve böylece imlâ (yazım) farkları ortaya konacaktır. Çalışmanın son kısmında Rusça imlâ kaynaklı olmayan farklılıklara da değinilecektir. Bu farklılıklardan yola çıkarak sonuç kısmında öneri ve değerlendirmelerde bulunulacaktır.

Anahtar Sözcükler: Ortak İmlâ (Yazım), Rusça İmlâ (Yazım), Türk Dünyası.

\section{THE ISSUE OF COMMON WRITING (SPELLING) IN THE TURKIC WORLD}

\section{Summary}

Many steps have been taken towards the common written language and alphabet for the language unity of the Turkic world. However, these studies have not been sufficient for common writing, modern Turkic dialects that use both Cyrillic and Latin alphabets now apply the writing rules of Russian.

In this study, we will focus on attempts to create a common alphabet, and then the process of creating the writing rules of Russian which is widely used in contemporary Turkic dialects. Then under each article title, examples form Turkish, Russian and other contemporary Turkic dialects will be given. And thus writing (spelling) differences will be revealed. In the last part of the study, non-Russian language differences will also be mentioned. Based on these differences, suggestions and evaluations will be made in the conclusion part.

Key Words: Common Writing (Spelling), Russian Writing (Spelling), Turkic World.

\footnotetext{
* Bu makale, 17-19 Ekim 2018'de Eskişehir'de Eskişehir Osmangazi Üniversitesi ile Türk Dil Kurumu tarafından düzenlenen 10. Uluslararası Dünya Dili Türkçe Sempozyumu'na sunulmuş bildirinin yeniden gözden geçirilmiş ve düzenlenmiş biçimidir.

** Dr. Öğr. Üyesi, Fırat Üniversitesi / İnsani ve Sosyal Bilimler Fakültesi, Çağdaş Türk Lehçeleri ve Edebiyatları Bölümü, el - mek: mehmetozeren@hotmail.com
}

DRCID ID: orcid.org/0000-0003-4386-8312 


\section{Giriş}

\subsection{Türk Dünyasında Ortak Alfabe ve İmlâ (Yazım) Girişimleri}

Türkçe, 13. yüzyıla kadar tek bir yazı dili olarak kullanılırken, bu yüzyıldan 20. yüzyıla kadar Türkistan (Harezm, Kıpçak ve Çağatay Türkçeleri) ve Anadolu (Eski Anadolu Türkçesi, Osmanlı Türkçesi) coğrafyalarında ayrı yazı dilleri olarak varlığını sürdürmüştür. 19. yüzyılın sonlarına doğru İsmail Gaspıralı'nın “dilde, fikirde, işte birlik” ülküsüyle savunduğu ortak yazı dili ve alfabe konuları Türk dünyasında heyecan yaratmıştır. Buna karşılık Çarlık Rusyası döneminde kurulan Tüzem mekteplerinde N. İ. İlminskiy ve 20. yüzyılın başlarında yaşanan gelişmelerin sonucunda farklı alfabeler ile Türk boyları için ayrı ayrı yazı dilleri oluşturulmuştur. Türk dünyasında ortak yazı dili ve alfabe çalışmaları için atılan en olumlu somut adım ise I. Bakü Türkoloji Kurultayı olmuştur. Kurultayda ortak alfabe, imlâ, terminoloji ve yapılması gereken çalışmalar değerlendirilmiştir ${ }^{1}$. Ortak alfabe konusunda Latin alfabesine geçilmesi veya Arap alfabesinin kullanılmaya devam edilmesi üzerinde yoğunlaşan tartışmalar neticesinde 34 harften oluşan Ortak Türk Alfabesi kabul görmüştür. Türk topluluklarında Latin alfabesinin kullanımı on yıl kadar devam etmiş̧tir. Ancak 1936'da Türkmenistan'da yapılan "Türkmenoloji Kongresi” ile I. Bakü Türkoloji Kurultayı'nda alınan kararlar uygulamadan kaldırılmış ve Kiril alfabesine geçiş yönünde görüşler benimsenmiştir. Böylelikle Türk topluluklarının her biri için ayrı ayrı hazırlanmış olan ve günümüze kadar kullanılan Kiril alfabesine geçilmiştir. 1992'de Bişkek'te toplanan Türk Cumhuriyetleri Eğitim Bakanları ve Türk Toplulukları Eğitim Temsilcileri II. Konferansı'nda, 1993’te Türk İşbirliği ve Kalkınma Ajansı tarafından Ankara'da düzenlenen alfabe ve imlâ konferansında, yine 1993'te Antalya'da yapılan Türk Devlet ve Toplulukları Dostluk-Kardeşlik ve İşbirliği Kurultayı'nda ortak alfabe konuları tartışılmış ve sonuçta 34 harfli "Ortak Türk Alfabesi” onaylanmıştır². Ancak daha sonra bağımsız Türk Cumhuriyetlerindeki farklı gelişmeler doğrultusunda Azerbaycan, Türkmenistan, Özbekistan ve Kazakistan birbirinden farklı Latin alfabesine geçme yönünde kararlar almışlardır.

Şüphesiz ortak yazı dili ve alfabe yönünde atılan adımlar, Türk dünyasının birlikteliği açısından son derece olumlu adımlardır; ancak ortak imlâ (yazım) için yeterli değildir. Bugüne kadar yapılmış çalışmalar ortak alfabe ve yazı diline odaklanmış durumdadır. Oysaki ortak alfabe, bir dildeki imlâ kurallarının sadece ses-harf yönü ile ilgilidir. Genel anlamda imlâ ise, bir dilin söz varlığını o dilde yürürlükte olan ses, şekil, köken vb. kurallara uygun olarak yazıya geçirme; dildeki sözleri belirlenen kurallara uygun olarak yazma anlamına gelmektedir ${ }^{3}$. Bugüne kadar yapılan çalışmalarda çağdaş Türk lehçelerinde ortak yazım kurallarını oluşturma noktasına ulaşılamamıştır. Oysaki Sovyetler döneminde Türk lehçelerinin yazı dilleri oluşturulurken Rusça ile ortak olan Kiril alfabesi ve Rusça imlâ (yazım) kuralları dayatılmıştır ${ }^{4}$. İmlâ (yazım) kuralları ile ilgili tartışmalar ise daha çok Rusça için kullanılan Kiril alfabesinde olmayan ama Türk lehçelerinde yer alan "ö, ü, $\breve{g}$, ñ, c" gibi sesleri karşılayacak harfler

\footnotetext{
${ }^{1}$ Ahmet Buran (2009), “Sovyet Türkolojisi ve Birinci Türkoloji Kurultayı”, Turkish Studies, C. 4/3, s. 438.

${ }^{2}$ Rakhat Abdieva, "Bağımsızlıklarını Kazandıktan Sonra Türk Cumhuriyetlerinin Dil Politikaları ve Türkiye İle Ortak Dil ve Ortak Alfabe Çalışmaları", Uluslararası Türk Lehçe Araştırmaları Dergisi (TÜRKLAD), Cilt 1, Say1 2, 2017, s. 105-107.

${ }^{3}$ http://www.tdk.gov.tr/index.php?option=com bts\&arama=kelime\&guid=TDK.GTS.5bc09f7e8c6fb3.18821964 $(12.10 .2018)$

${ }^{4} 1926$ Bakü I. Türkoloji Kurultayı'na katılan L. V. Şçerba burada “Orfografiyanın Negizgi Printsipteri cana Anın Sotsialdık Maanisi" adlı bir bildiri sunmuş ve bildiride imlânın eğitime katkısının büyük olduğunu, geniş Rus coğrafyasında yaşayan yüz elli milyon Rus halkının aynı tarzda konuşmasının mümkün olmadığını ancak aynı biçimde yazması gerektiğini belirterek ortak Rus imlâsını savunmuştur. Bk. H. K. Karasaev, Kırgız Tilinin Orfografiyalık Sözdügü, Bişkek 2009, s. 9.
} 
üzerinden yürümüş ve Türk lehçelerinde kullanılan alfabelerde dönem dönem ekleme ve çıkarmalar olmuştur ${ }^{5}$.

Ancak son dönemlerde Latin alfabesine geçişin yanı sıra Türk lehçelerinin imlâ (yazım) sorunları yer yer tartışılmaktadır. Örneğin Kazakistan, Latin alfabesine geçme kararının ardından 2018 yılında yapılan çalışmayla 19 temel maddeden oluşan yazım kuralları oluşturma çabasındadır 6 . Son olarak 1981 yılında kabul edilen Altay Türkçesinin imlâ (yazım) kuralları 2012 yılında Gorno Altay'da tartışılmış, isim ve fiillerde ortak yazım kuralları belirlenmek istenmiştir ${ }^{7}$. Özbek Türkçesinin imlâ (yazım) kuralları V. F. İvanov'un Rusça imlâ için yazdığ 1 "Printsipı russkoy orfografii" (Rusçanın İmlâ Prensipleri) adlı esere dayanılarak 4 Temmuz 1940 tarihinde yeni alfabe komisyonu tarafindan belirlenmiş ve bu kurallar 1952, 1953 ve 1955 yıllarında tekrar yayınlanmış, 4 Nisan 1956 tarihinde ise son biçimi Yüksek Sovyet Şurası tarafından onaylanmıştır. Latin alfabesine geçildikten sonra 24 Ağustos 1995 tarihinde Özbekistan Bakanlar Kurulu'nun 339 sayılı kararı ile yeni imlâ kuralları yayınlanmıștır. Kiril ve Latin alfabesi için sunulan imlâ önerileri Özbek Türkçesi imlâ sorunlarını giderememiştir ${ }^{8}$. Kırgız Türkçesi için oluşturulan 31 harfli Latin alfabesi ile kullanılacak imlâ kurallarında ${ }^{9}, 12$ Eylül 1941 tarihinde Yüksek Sovyet Şurası tarafından kabul edilen Kiril alfabesi ile kullanılacak imlâ kurallarında Rusça imlâdan yararlanılmış ve 1947 'de, 1953 'te bu kurallarda bazı değişiklikler yapılmıştır ${ }^{10}$. H. Karasaev, 60 bin sözcüğü içeren Kırgız Türkçesinin ilk imlâ sözlüğünü “Kırgız Tilinin Orfografiyalık Sözdügü” adıyla 1966 yılında yayınlamıştır. Bu sözlük 1983 yılında tekrar yayınlanmıştır" ${ }^{11} 1950$ - 1960 yıllarında Kırgız Türkçesi imlâsında Rusçadan alıntı kelimelerin yazımı ile ilgili yoğun tartışmalar yaşanmışıır' ${ }^{12} .1995$ ve 2002 yıllarında ise bazı imlâ önerileri olmuş ancak bunlar uygulamaya konulamamıştır ${ }^{13}$. 26 Haziran 2008 tarihinde Kırgızistan Yüksek Meclisi'nin 567 sayılı kararıyla yeni imlâ kuralları belirlenmiştir. Bu kurallar doğrultusunda ve H. K. Karasaev'in 1983 yılında yayınladığı imlâ kılavuzu temelinde "H. K. Karasaev, Kırgız Tilinin Orfografiyalık Sözdügü, Bişkek 2009" adıyla yeni bir imla kılavuzu yayınlanmıştır ${ }^{14}$.

\footnotetext{
5 Voprosı Soverşenstvovaniya Alfavitov Tyurkskih Yazıkov SSSR, Ot. Red.: N. A. Baskakov,İzdatel'stvo "Nauka”, Moskva 1972; A. E. Çumakaev, “O Nekotorıh Aktual'nıh Voprosah Orfografii Sovreennogo Altayskogo Yazıka", Aktual'nı Voprosı Altayskogo Yazıkoznaniya: Problemı Razvitiya Literaturnogo Yazıka, Soverşenstvovanie Sovremennoy Orfografii, Red.: M. S. Dedina, N. V. Ekeev, A. N. Mayzina, A. E. Çumakaev (sor. red.), Pravitel'stvo Respubliki Altay Ministerstvo Obrazovaniya i Nauki Respubliki Altay, Gorno-Altaysk 2017, s. 36 .

${ }^{6}$ https://www.zakon.kz/4934407-u-novoy-orfografii-kazahskogo-yazyka.html (26.10.2018)

${ }^{7}$ https://www.gorno-altaisk.info/news/18490 (26.10.2018)

${ }^{8}$ Hasanxon Jamolxonov, Hozirgi O‘zbek Adabiy Tili, Talqin, Toshkent 2005, s. 108. Ancak Özbek Türkçesinin 1995 yılında kabul edilen imla kurallarında 1956'ya göre bazı farklılıklar olmuştur. Bk.: Hasanxon Jamolxonov, age., s. $107-114$.

${ }^{9}$ K. Bakeev - İ. Batmanov - U. Baktıbaev, Novaya Orfografiya Kirgizskogo Yazıka, Kırgızmambas, Frunze 1938.

${ }^{10}$ H. Karasaev - Yu. Yanşansin, Kırgız Tilinin Orfografiyası, SSSR İlimler Akademiyasının Kırgız Filialı; Til, Adabiyat cana Tarih İnstitutu, Frunze 1947, s. 3; H. K. Karasaev, age., s. 11

${ }^{11}$ H. K. Karasaev, age., s. 10.

12 Tartışmalar Rusçadan alıntı her sözcüğün Rus imlâsına göre yazılacağı (İ. A. Batmanov, A. Altımışbaev) ile 1917 Ekim devrimi öncesinde ve sonrasında olmak üzere iki farklı dönemde giren Rusçadan alıntıların iki farklı şekilde yazılması (K. K. Yudahin, B. M. Yunusaliev ve K. Karasaev'e göre 1917 Ekim devrimi öncesinde Rusçadan alıntıların söylenildiği gibi, devrim sonrası dile giren alıntıların ise Rus imlâsına göre yazılmalıdır.) gerektiği üzerinden olmuştur: Bk. H. K. Karasaev, age., s. 19.

131953 ’teki kurallar ile 1995, 2002 yıllarındaki imlâ önerilerini karşılaştırınız: Bk. H. K. Karasaev, age., s. 11-12.

${ }^{14}$ H. K. Karasaev, age., s. 5.
} 
Görüldüğü üzere Sovyetlerin etkisi altında kalmıș Türk lehçeleri günümüzde ister Kiril alfabesi isterse Latin alfabesi kullansın, büyük oranda Rusça imlâ (yazım) kurallarına göre yazmayı sürdürmektedirler.

\subsection{Rusçanın İmlâ (Yazım) Kuralları Çalışmalarının Geçmişi}

Eski Rusça (X-XII. yüzyıllar), konuşulduğu gibi yazılan fonetik özellikte iken ${ }^{15}$, XII XVII. yüzyıllar arasında Rus yazı sisteminin fonetik yapısı çok değişmiştir. Bu da yazının telaffuzdan önemli ölçüde farklılaşmasına neden olmuş ve böylelikle telaffuz yazıyı etkilemeye başlamıştır. Daha önce kelimeler arasında boşluk yok iken XVI. yüzyılda metinler kelimelere ayrılmaya, büyük harfler kullanılmaya başlanmıştır. XVII. yüzyılda Rusçanın yazımı ile ilgili ilk çalışmalar yapılmıştır. Bunlar arasında en tanınmış çalışma M. G. Smotritsky'nin çalışmasıdır. Bu çalışmada bazı yazım kuralları teklif edilmiştir. Yazım ile ilgili büyük sorunlar XVIII. yüzyılda ortaya çıkmıştır. Bu dönem yazarları imlâ farklılıklarından şikâyetçi olmuşlar ve yazı dilinin telaffuzuna dayalı yeni prensipler önermişlerdir ${ }^{16}$. M. V. Lomonosov, 1757 yılında yayınlanan "O pravopisanii" (İmla Üzerine) adlı çalışmasında lehçe ve ağız farklılıkları nedeniyle sadece bir telaffuzun olmayışını göz önüne alarak, tarihsel geleneği de göz önünde bulunduran uygun morfolojik ve fonetik yazım prensiplerini savunmuştur. XIX. yüzyılın ilk yarısında N. İ. Greç, A. H. Vostokov, İ. İ. Davıdov, F. İ. Buslaev'in gramer kitapları imlâ uyumu açısından olumlu rol oynamıştır. Ancak yine de imlâda düzensizlikler görülmüştür. Rusçanın imlâsı ile ilgili Y. K. Grot'un 1873 yılında yayınlanan "Spornıe Voprosı Russkogo Pravopisaniya ot Petra Velikogo Donıne" (Büyük Petro'dan Bugüne Rus İmlasının Tartışmalı Sorunları) adlı çalışması ile 1885 yılında yayınladığı "Russkoe Pravopisanie" (Rusça Yazım) adlı çalışması Rusçanın imlâsına oldukça düzen getirmiştir. 1904 yılında İlimler Akademisi İmla Komisyonu oluşturmuş, ancak alt komisyon üyelerinin daha sade yazım önerileri kabul edilmemiștir.

Rus imlâs1 sadece Sovyet hükümetinin 13 Ekim 1918 tarihli Halk Komiserleri Konseyi kararnamesiyle sadeleştirilebilmiştir. Ancak imlâ sorunları (örneğin birleşik kelime yazımı (bez uderju, bezuderju), çift ünsüzlerin yazımı (gallereya, galereya) vb.) bu tür kararnamelerle ortadan kaldırılamamıştır. Çünkü uygulama, yazımın daha da basitleştirilmesini ve sistemleştirilmesini gerektirmiştir. 1929 yılında imlâ sorunlarını görüşmek üzere Eğitim Bakanlığı bünyesinde Halk İmla Komitesi oluşturulmuş ancak 1930 y1lında bu komisyonun hazırlamış olduğu proje kabul edilmemiştir ${ }^{17}$.

1930'lu yıllarda yazım ve noktalama ile ilgili SSCB İlimler Akademisi ile hükümet bünyesinde birkaç komisyon daha oluşturulmuştur. Bu komisyonların çalışmaları sonucunda 1940 yılında "Pravil Edinoy Orfografii i Punktuatsii" (Ortak İmla Kuralları) adlı taslak çalışma ile kısa bir imlâ kılavuzu yayınlanmıştır. Böylelikle ilk kez Rusça imlânın temel kuralları uygulama yapılan eğitim kurumları ve yayınevleri de dikkate alınarak geniş bir çerçevede ele alınmıştır. Yine de bu taslak çalışmanın bazı yerlerinin iyileştirilmesi gerekmesine rağmen 2 . Dünya Savaşı nedeniyle buna ara verilmek zorunda kalınmıştır. Ancak 1947 yılında hükümetin imlâ komisyonu "Edinogo Svoda Pravil Russkoy Orfografii i Punktuatsii" (Rusça Yazım Kuralları ve Noktalama İşaretleri İle İlgili Ortak Kanun) adıyla yeni bir taslak yayınlayabilmiştir. 1950 yılındaki dil tartışmalarında da imlâ konusuna değinilmiş ve imlâ kuralları ile ilgili birtakım değişikliklere gidilmiştir. 1951 - 1954 yılları arasında imlâ komisyonu ortak kanunun geliştirilmesine yönelik çalışmalarına devam etmiştir. 1954 yılında gazete ve dergi sayfalarında öğretmen, öğrenci, akademisyen ve yayıncıların da katıldığı Rusça imlâ sorunları ve kanun taslağı ile ilgili geniş tartışmalar yapılmıştır. 1956 yılında SSCB İlimler Akademisi, SSCB Yükseköğretim ve Eğitim Bakanlığı tarafından onaylanan "Rusça İmla

\footnotetext{
${ }^{15}$ N. M. Şanskiy - V. V. İvanov, Sovremennıy Russkiy Yazzk, Moskva 1987, s. 186.

${ }^{16}$ A. N. Kaydalova, N. K. Kalinina, Sovremennaya Russkaya Orfografiya, Moskva 1983, s. 5.

${ }^{17}$ A. N. Kaydalova, N. K. Kalinina, age., s. 6.
} 
Kuralları"na bu tartıșmalardan doğan bir dizi teklif yansıtılmıștır. Böylelikle Rusçanın gelișmesi için imlâ kurallarının önemi vurgulanmış, herkes ve her kurum için ilk kez resmi olarak onaylanmış imlâ kuralları zorunlu hale getirilmiştir. Bu kurallara göre S. İ. Ojegov ve A. B. Şapiro redaktörlüğünde hazırlanmış olan "Orfografiçeskiy Slovar' Russkogo Yazıka" (Rusçanın İmla Kılavuzu) adlı çalışma 1956 yılında yayınlanmıştır. Bu kılavuzun 19. baskısı S. G. Barhudarov, İ. F. Protçenko, L. İ. Skvortsov redaktörlüğünde 1982 yılında tekrar yayınlanmıştır. $\mathrm{Bu}$ kılavuz Rusçanın imlâsında önemli rol oynasa da birtakım imlâ sorunlarını (birleşik sözcükler, edatlar, ön takı ne vb.) çözememiştir ${ }^{18}$.

Son olarak 1956 yılında şekillendirilen Rusçanın imlâ (yazım) kuralları, Sovyet yönetimi altında kalmış olan Türk lehçelerinin yazımına da yansımıştır. Rusçanın imlâ (yazım) kuralları sadece Rusçadan alıntı sözcüklerde kullanılmakla kalmamış ${ }^{19}$, çağdaş Türk lehçelerine ait sözcük ve cümlelerde de kendisini göstermiştir.

Günümüzde çağdaş Türk lehçeleri ile Türkiye Türkçesi arasında büyük oranda farklılık gösteren imlâ (yazım) ve noktalama kuralları şunlardır:

\section{Türkiye Türkçesi ile Çağdaş Türk Lehçelerindeki İmlâ (Yazım) Kurallarının Karşılaştırılması}

\subsection{Büyük - Küçük Harf Kullanımı}

2.1.1. Türkiye Türkçesinde kurum, kuruluş ve kurul adlarının her sözcüğü büyük harfle başlar: Türkiye Büyük Millet Meclisi, Türk Dil Kurumu, Dil ve Tarih-Coğrafya Fakültesi, Türk Dili ve Edebiyatı Bölümü (YK, s. 15-16). Azerbaycan ve Gagavuz Türkçelerinde de bu yazım kuralı uygulanmaktadır:

Azerbaycan Türkçesinde: Azerbaycan Milli Elmler Akademiyası Nesimi adına Dilçilik İnstitutu, Azerbaycan Respublikasının Milli Meclisi, Azerbaycan Respublikasının Nazirler Kabineti, Azerbaycan Respublikasının Harici İşler Nazirliyi (ADOQ, s. 10).

Gagavuz Türkçesinde: Komrat Devlet Universitetında, Büükelçililiklerin Kulturaları Koruma Fondu (AS).

Rusçada ise kurum, kuruluş ve kurul adlarının sadece ilk harfi büyük, diğerleri küçük harf ile başlar: Muzey istorii Moskvı, İnstitut russkogo yazıka imeni A. S. Puşkina, Kazanskiy universitet, Moskovskaya gosudarstvennaya konservatoriya, Rossiyskaya akademiya nauk, Mejdunarodnıy valyutnı fond, Moskovskaya gorodskaya duma, Federal'noe agenstvo po fiziçeskoy kul'ture, sportu i turizmu, Gosudarstvenniy komitet Rossiyskoy Federatsii po statistike (PROP, s. 165, 175, 182).

Çağdaş Türk lehçelerinde de Rusça yazım kuralının devam ettiği görülür:

Başkurt Türkçesi: Kent qunaqxanahında (ÇTYD3, s. 274)

Kazak Türkçesi: Kazak SSR Ğılım akademiyası, Til bilimi institutınıñ, Memlekettik emtixan komissiyasınıñ, Kızdar pedagogtık institutı, Abay atındağı Almatı memlekettik universiteti, Kazakstan Respublikası joğarı attestatsiyalık komissiyasınıñ (KTTD, s. 3, 6), "Kazak tili” koğamı (KTA, s. 114).

\footnotetext{
${ }^{18}$ A. N. Kaydalova, N. K. Kalinina, age., s. 7-8; N. M. Şanskiy - V. V. İvanov, age., s. 186-189.

19 Özellikle 1917 Ekim Devrimi sonrası Rusçadan alıntı sözcükler Rusça imlaya göre yazılmaktadır. Bk.: Ayşe Nuriahmetova, "Günümüz Kırgız Türkçesinde Rusça Unsurlar", JASSS, Number 27, Autumn I 2014, p. 333 - 347 ; Emine Atmaca, "Kazak Türkçesinin Söz Varlığındaki Rusça Alıntılar ve Ses Değişmeleri”, Turkish Studies, Vol. 7/3, Summer 2012, p. 275 - 298; Mehmet Özeren, "Kırgız Türkçesindeki Rusça Alıntı Sözcükler ve Bu Sözcüklerdeki Ünsüz Olayları", Zeitschrift für die Welt der Türken Journal of World of Turks, Vol. 2, No. 2 (2010), s. 227-241.
} 
Kırgız Türkçesi: Uluttuk ilimder akademiyası, Kırgız uluttuk universiteti, Bilim berüü cana ilim ministirligi, Mayıp baldardı koldoo fondu, Turizm cana sport boyunça agenttigi, Mamlekettik til boyunça uluttuk komissiya, Kırgız uluttuk universitetinin filologiya cana kırgız taanuu fakul’teti, Til cana adabiyat institunun azırkı kırgız tili sektörü (KTCE, s. 8, 10).

Özbek Türkçesi: Mirzo Ulug'bek nomidagi O’zbekiston Milliy universiteti, Nizomiy nomidagi Toshkent Davlat pedagogika universiteti, Ichki ishler bo'limi boshqarmasi, Davlat avtoinspeksiya nazorati, Buxoro Davlat universiteti (HOAD, s. 2, 13).

Tatar Türkçesi: Törkiye cömhuriyetǐnı̆n devlet tịlǐ (ÇTYD3, s. 81).

Türkmen Türkçesi: TSSR Ilımlar akademiyasının (TD, s. 3).

2.1.2. Türkiye Türkçesinde kişi adları ve soyadlarının her sözcügü büyük harfle yazılır ve soyadlarındaki "oğlu, kızı" ifadeleri bitişik yazılır: Karamanoğlu, Karaosmanoğlu vb. Kazak Türkçesinde de aynı yazım kuralının uygulandı̆̆ı görülmektedir:

Kazak Türkçesi: Ö. Aytbayulı, B. Äbilkasımulının (KTTD, s. 2, 7).

Rusçada ise soyadlarındaki "oğlu, kızı" ifadeleri “_” işareti ile ayrı ve küçük harfle yazılır: Tursun-zade, Mamed-ogl1, Yaver-kızı (PROP, s. 131), Agamali-ogl1 (OP, s. 130).

Çağdaş Türk lehçelerinde de Rusça yazım kuralının kısmen veya tam olarak devam ettiği görülür:

Azerbaycan Türkçesi: Ebdülhüseyn oğlu Hacıbeyli (ADOQ, s. 9).

Gagavuz Türkçesi: Yarun - Oguz Karahan oglu (GDL, s. 136).

Kazak Türkçesi: Tursun-zade (KTA, s. 53).

Kırgız Türkçesi: Kasım Tınıstan uulu, Buudaybek Sabır uulu, Nazira Aalı kızı (KTCE, s. 9).

Özbek Türkçesi: Abdulhamid Sulayman o'g'li Cho'lpon (ÇTYD2, s. 91).

Tuva Türkçesi: A. A. Aldın-ool, May-ool Çoodunuu (BN, s. 1, 2).

2.1.3. Türkiye Türkçesinde özel adlardan türetilen bütün kelimeler büyük harfle başlar: Türklük, Türkçülük, Darvinci, Asyalılık (YK, s. 17) vb.

Rusçada ise özel adlardan türetilen bütün kelimeler küçük harfle başlar: darvinovskoe uçenie, bethovenskaya sonata, şekspirovskie tragedii, puşkinskaya garmoniya, nitsşeanets, tolstovstvo, darvinizm, puşkiniana, leniniana (PROP, s. 170, 171) vb.

Çağdaş Türk lehçelerinde de Rusça yazım kuralının devam ettiği görülür:

Başkurt Türkçesi: törökse (ÇTYD3, s. 275).

Kırgız Türkçesi: lenindik-stalindik, leninçil, ala-tooluk el, moskvalık, stahanovçu (KTO, s. 8), marksizm, manasçı, lenindik, gegelçil (KTCE, s. 9).

Kazak Türkçesi: mäskewlik, kiyevtik, semeylik, altaylık (KTA, s. 59).

Nogay Türkçesi: qazanlı (ÇTLMA, s. 535).

Tatar Türkçesi: rusça, törikçe - tatarça (ÇTYD3, s. 74).

Özbek Türkçesi: turkiy til (HOAD, s. 21).

2.1.4. Türkiye Türkçesinde kişi adlarından önce ve sonra gelen unvanlar, saygı sözleri, rütbe adları, lakaplar ve akrabalık adları büyük harfle başlar: Kaymakam Erol Bey, Mustafa Efendi, Zeynep Hanım; Bay Ali Çiçek, Deli Petro, Sayın Prof. Dr. Hasan Eren; Gül Baba, Susuz Dede, Telli Baba, Baba Gündüz, Nene Hatun (YK, s. 14) vb. 
Rusçada ise bir özel isimden sonra gelen "bey, hanım, ağa, paşa, han, şah" gibi unvanlar kısa çizgi ile ayrı ve küçük harf ile yazılırlar: İzmail-bey, Kemal'-paşa, Mirza-han, Ahmed-şah (PROP, s. 131), Aşik-paşa, Suleyman-paşa (OP, s. 130) vb. Rusça imlâda özel isimden önce gelen saygı ifadeleri de küçük harf ile başlar: gospodin İvanov, mister Smit, mademuazel' Cyuli (PROP, s. 128) vb.

Çağdaş Türk lehçelerinde de Rusça yazım kuralının devam ettiği görülür:

Altay Türkçesi: May-ene, Pay-ana, Bay-ene (ÇTLMA, s. 700).

Azerbaycan Türkçesi: Üzeyir bey, Nadir şah, Abbas ağa, Feteli xan, Heyran xanım (ADOQ, s. 10-11).

Kazak Türkçesi: Birjan sal, Akan seri, Kambar batır, Bayan suluw, Jirenşe şeşen, Ayaz biy, İygilik biy, Kürenköz koja (KTA, s. 42), Nahas-paşa, İzmail-bey, Abdulla-bek, muğalim Murat, Murat muğalim (KTA, s. 53, 58).

Kırgız Türkçesi: Adam ata, Umay ene, Oysul ata, Çolpon ata, Zeñgi baba (KTCE, s. 9).

Nogay Türkçesi: Dcumay - atay (ÇTLMA, s. 532).

Tatar Türkçesi: Bilge - kagan (ÇTYD3, s. 79).

2.1.5. Türkiye Türkçesinde millet, boy, oymak adları büyük harfle yazılır: Türk, Kazak, Kırgız, Oğuz, Özbek, Tatar, Karakeçili (YK, s. 14) vb.

Rusçada ise millet, boy, oymak adları küçük harfle yazılır: tyurkskie, persidskie, ispanskie, portugal'skie (PROP, s. 130, 131), rus (SRO, s. 3, 4) vb.

Çağdaş Türk lehçelerinde de Rusça yazım kuralının devam ettiği görülür:

Altay Türkçesi: türk, kırkıs, başkort, kazah, türkmen, uzbek, azerbaycan, karaçay, tıva, hakas (ÇTLMA, s. 712), altay (AVAY, s. 97).

Azerbaycan Türkçesi: türk (ADE, s. 38), türkmen ve yakut dillerinde (ADE, s. 25), özbek, qazax, qaraqalpaq, qırğız, noqay, oyrot (ADE, s. 50), başqırd (ADE, s. 51).

Başkurt Türkçesi: başqort (ÇTYD3, s. 276).

Çuvaş Türkçesi: çॅvaş (ÇTLMA, s. 798).

Gagavuz Türkçesi: oguz, kıpçaklar, peçeneklär, gagauz (GDL, s. 138, 139).

Hakas Türkçesi: amerikanets, nemets, hakas (HOS, s. 13, 64, 127), orıs, hakas (Ç, s. 7).

Karaçay-Balkar Türkçesi: türk, tacik, fars (ÇTYD3, s. 588).

Karakalpak Türkçesi: qaraqalpaq, rus, özbek (ÇTYD3, s. 463).

Kazak Türkçesi: kazak jäne orıs tilderinde, türk uñgularının, kıpşak tiliniñ, arabşa nuska (KTTD, s. 3, 5, 7).

Kırgız Türkçesi: solto, sayak, kıdık, orus, hakas, sarbagış, karakıtay, otuzuul, kuu uul (KTCE, s. 9).

Kumuk Türkçesi: qumuq (ÇTYD3, s. 529).

Nogay Türkçesi: noğay, uyğır (ÇTLMA, s. 516, 523).

Özbek Türkçesi: o'zbek, arab, fors (HOAD, s. 3, 10), özbek, tåcik, rus, ukrain, inglis, nemis, arab, ispan, fårs, o'zbek (ÇTYD2, s. 85, 91).

Tatar Türkçesi: başqort, nugay, komık, uygur, karakalpak, balkar, törı̌k, kırgız, törǐkmen, tuva, xakas, altay (ÇTYD3, s. 79), uqrain, qazaq (ÇTLMA, s. 382, 398). 
$5)$.

Türkmen Türkçesi: türkmen (TD, s. 3), rus alım, Eyran-Astrabat türkmenlerinin (TD, s.

Yakut Türkçesi: uon ikki xahaaxtaax (on iki Kazak), buryat (ÇTLMA, s. 593, 596).

2.1.6. Türkiye Türkçesinde yer adlarında ilk isimden sonra gelen ve deniz, nehir, göl, dağ, boğaz vb. tür bildiren ikinci isimler ile "mahalle, meydan, bulvar, cadde, sokak" kelimeleri, dükkân, mağaza adları büyük harfle başlar: Ağrı Dağı, Aral Gölü, Dicle Irmağı, Ege Denizi, Erciyes Dağı, Fırat Nehri, Van Gölü; Yunus Emre Mahallesi, Karaköy Meydanı, Zafer Meydanı, Gazi Mustafa Kemal Bulvarı, Nene Hatun Caddesi, Cemal Nadir Sokağı, İnkılap Sokağı (YK, s. 15) vb.

Rusçada ise yer adlarında ilk isimden önce ya da sonra gelen ve deniz, nehir, göl, okyanus, dağ, boğaz vb. tür bildiren ikinci isimler ile "mahalle, meydan, bulvar, cadde, sokak" kelimeleri, dükkân, mağaza adları küçük harfle başlar: Beloe more, Golodnaya step', Abissinskoe nagor'e, Onejskoe ozero, Severnıy Ledovitıy okean, plato Ustyurt, Krasnodarskiy kray, Orlovskaya oblast', Şçyolkovskiy rayon, Tverskaya ulitsa, Arbatskaya ploşçad', Tsvetnoy bul'var, ulitsa 1905 goda, Bol'şoy Kamennıy most (PROP, s. 172), ozero Baykal, Atlantiçeskiy okean, Ural'skie gorı, ploşçad' Svobodı, ulitsa Sadovaya, Liteynıy prospekt (OS, s. 202)

Çağdaş Türk lehçelerinde de Rusça yazım kuralının devam ettiği görülür:

Azerbaycan Türkçesi: Hezer denizi, Azadlıq meydanı, Şuşa qalası (ADOQ, s. 9). s. 59, 60).

Kazak Türkçesi: Kaspiy teñizi, Tınık muhit, Sadovo-Kudrinsk köşesi, Kızıl alan (KTA,

Kırgız Türkçesi: Aral deñizi, Balkaş kölü, Suusamır öröönü, Cazı darıyası, Çoñ-Sarı-Oy ayıl1, "Ala-Too" ayantı, "Erkindik" gülbagı, "Baysuu" kafesi, "Aysuluu" suluuluk salonu, "Bişkek" meymankanası, "Cırgal" monçosu, "İlim" basması, "Çolpon" but kiyim tigüü fabrikas1, "Kıyal" birikmesi (KTCE, s. 10).

Özbek Türkçesi: Maksim Gor'kiy köçäsidä, Qatorterak mahallasida (ÇTYD2, s. 88).

2.1.7. Türkiye Türkçesinde ulusal, resmî ve dinî bayramlarla anma ve kutlama günlerinin adları, tarihi olay, çağ ve dönem adları büyük harfle başlar: Cumhuriyet Bayramı, Ulusal Egemenlik ve Çocuk Bayramı, 19 Mayıs Atatürk'ü Anma Gençlik ve Spor Bayramı, Ramazan Bayramı, Kurban Bayramı, Nevruz Bayramı, Miraç Kandili; Anneler Günü, Öğretmenler Günü, Dünya Tiyatro Günü, 14 Mart Tıp Bayramı, Hıdırellez, Kurtuluş Savaşı, Millî Mücadele, Cilalı Taş Devri, İlk Çăg, Lale Devri, Cahiliye Dönemi, Buzul Dönemi, Millî Edebiyat Dönemi, Servetifünun Dönemi’nin, Tanzimat Dönemi’nde (YK, s. 16, 17) vb.

Rusçada ise dönemleri, tarihi olayları, dinî ve resmî günleri ifade ederken yalnızca ilk harf büyük harf ile yazılır: Srednie veka, Pervaya mirovaya voyna, Oktyabr'skaya revolyutsiya, Noviy god, Pervaya maya, Den' nezavisimosti, Velikiy çetverg (PROP, s. 177, 180), Russko turetskaya voyna (OP, s. 133) vb.

Çağdaş Türk lehçelerinde de Rusça yazım kuralının devam ettiği görülür:

Azerbaycan Türkçesi: Veten müharibesi, Yeddiillik muharibe, Versal sülhü, Demir dövrü, Çaldıran döyüşü (ADOQ, s. 9).

Hakas Türkçesi: Tun payramda (ÇTLMA, s. 630), Oktyabr’ revolyutsiyazınıñ (Ç, s. 23).

Kırgız Türkçesi: Cañı c1l mayramı, Brest tınçtıgı, Tegeran kelişimi, Basma söz künü, Nooruz mayram1, Orozo ayt (KTCE, s. 10).

Nogay Türkçesi: “sabantoy” bayramı (ÇTLMA, s. 516).

Türkmen Türkçesi: Beyik Oktyabr’ sotsialistik revolyutsiyasından (TD, s. 3). 
2.1.8. Türkiye Türkçesinde kitap, dergi, gazete ve sanat eserlerinin (tablo, heykel, beste vb.) her kelimesi büyük harfle başlar: Kendi Gök Kubbemiz, Anadolu Notları, Sinekli Bakkal; Türk Dili, Türk Kültürü; Resmî Gazete; Kaplumbağa Terbiyecisi; Yorgun Herkül; Saraydan Kız Kaçırma, Onuncu Yıl Marşı (YK, s. 16) vb.

Rusçada ise kitap, dergi, gazete ve sanat eserlerinin adları tırnak içerisinde ve ilk harfi büyük olarak yazılırlar: "Voyna i mir", "Moskovskie novosti", roman "Dvoryanskoe gnezdo", rasskaz "Dama s sobaçkoy", gazetı "Argumentı i faktı", jurnalı "Novıy mir", sbornik "Sintaksis i stilistika" (PROP, s. 165, 186) vb.

Çağdaş Türk lehçelerinde de Rusça yazım kuralının devam ettiği görülür:

Altay Türkçesi: "Ulagannıñ ukaalu sözi” (AVAY, s. 103).

Azerbaycan Türkçesi: "Ata ve oğul" povesti, "Yeddi gözel" baleti, "Uzaq sahillerde" filmi, "Azerbaycan" qezeti (ADOQ, s. 10), "Azerbaycan dilinin Muğan qrupu şiveleri”, "İsmay1llı rayonu şiveleri” (ADE, s. 5, 6).

Gagavuz Türkçesi: Söz teoriyası, Çalışkan yardımcılar, Kosti yazı nicä geçirdi, Ariflik sizıntısı (GDL, s. 11, 13, 14, 26). 19).

Hakas Türkçesi: "Hızıl aal” (PUS, s. 10), Pos tiliniñ urog1, Urokta sispekter (Ç, s. 8,

Karakalpak Türkçesi: “Qırıq qız”, "Ronald haqqında jır” (ÇTYD3, s. 462).

Kazak Türkçesi: "Ana tili” gazeti, "Parasat" jurnalı, "Jalın" al'manahı, "Abay" romanı, "Şattık” simfoniyası, "Dala kızı" sureti, "Akku köli” baleti (KTA, s. 114).

Kırgız Türkçesi: "Leninçil caş", "Eki caş", "Uzak col”, "Leninizm maseleleri”, "Bolot kantip kurçudu" (KTO, s. 8), "Too arasında" romanı, "Kanıbek" romanı, "Sıngan bugu" küüsü, "Agım" geziti, "Uzak col" povesti (KTCE, s. 10).

Özbek Türkçesi: Hozirgi o'zbek adabiy tili, Umumiy tilshunoslik (HOAD, s. 15, 20), Mäktåb yårliqläri, Nizomiyning "Panj ganj" nomi bilan tarixga kirgan "Xamsa"si, ilk asari "Qurboni jaholat", ilk she'ri “Turkistonlik qardashlarimga" (ÇTYD2, s. 85, 89, 91).

Türkmen Türkçesi: “Ömür menzilleri” kitabını (TD, s. 3), "çagatay dilı" (TD, s. 5), Kazak Türkçesi: Dala välayatı gazeti (KTTD, s. 3).

\section{2. İkilemelerin Yazımı}

Türkiye Türkçesinde ikilemeler (yalın durumda, isim durum eklerini veya iyelik eklerini almış olabilirler) her durumda ayrı yazılırlar ve araya herhangi bir noktalama işareti getirilmez: adım adım, şıpır şıpır, üç beş, çoluk çocuk, soy sop, baş başa, elden ele, boşu boşuna, ucu ucuna, şıpır şıpır, tak tak, tıkır tıkır (YK, s. 24-25) vb.

Rusçada ise ikilemeler arasına kısa çizgi konulur: siniy-siniy, krepko-krepko, mnogomnogo, oçen'-oçen', sövsem-sovsem, grust'-toska, put'-doroga, jit'yo-bit'yo, gusi-lebedi, ovoşçi-fruktı, ruki-nogi, çelovek 12 - 15, yey let $30-35$, rubley $200-300$, eto bilo godu $\mathrm{v}$ 1950 - 1961-m, na den'-na dva, v yanvare-naçale fevralya, ah-ah, gav-gav, t'fu-t'fu, ay-ay-ay, mu-mu, nu-nu, oy-oy-oy, trah-tararah, çur-çura, bay-bay, ey-ey, e-ge-ge vd. (PROP, s. 119, 120, $122,149,150,163) \mathrm{vb}$.

Çağdaş Türk lehçelerinde de Rusça yazım kuralının devam ettiği görülür:

Altay Türkçesi: alar - alar, bala - barkazı, ada - enezi, emegen - öbögön, iyt - kuş, köp - köp (ÇTLMA, s. 690, 695, 696, 708), boy - boy1, başka - başka, kögüs - körümi (AVAY, s. 96, 97).

Azerbaycan Türkçesi: adda-budda, az-maz, qara-qura, qarma-qarışık, qonaq-qara, dediqodu, kağız-kuğuz, sür-sümük, aşıq-aşıq, top-top, ab-hava, alış-veriş, ölüm-itim, beh-beh, vay- 
vay, peh-peh, uy-uy, ha-ha-ha (ADOQ, s. 7, 8), ayrı-ayrı (ADE, s. 5), az-çox, bir-birine (ADST, s. 3, 4).

Başkurt Türkçesi: vaqıtı - vaq1t1, ata - baba, ağay - ĭnĭ (ÇTYD3, s. 277, 278, 279); boron - boron, ineler - ineler (ÇTLMA, s. 465).

Çuvaş Türkçesi: untalla - kuntalla "oraya buraya” (ÇTLMA, s. 797).

Gagavuz Türkçesi: biri - birinä, iki - üç ay, anası - bobası, set - set, başka - başka (GDL, s. 14, 19, 118).

Hakas Türkçesi: annañ - mınnañ, küzürt - hazırt (HOS, s. 15, 52), çir - suu, irek turah, idis - hamıst1, u - u (Ç, s. 5, 21, 27).

Karaçay-Balkar Türkçesi: cırlay - cırlay (ÇTYD3, s. 587).

Karakalpak Türkçesi: pada - pada, aş - arık, katar - katar (ÇTYD3, s. 469, 470).

Kazak Türkçesi: üsti-üstine, pay-pay, q1yın-q1stav, bir-eki, mäz-mäyram q1l-, qayqaydağı (B, s. 3, 4, 5, 7), uzın-1rğa, sır-sıpat, birden-bir, oku-ağartu, tüzdön-tüz (KTTD, s. 4, 7, 9).

Kırgız Türkçesi: baq-daraq, arq1-berki (NOKY, s. 6, 7), bala-bakıra, kempir-kesek, olbuy-solbuy, ayıl-apa, 1ykı-tıykı (KTO, s. 12),biri-birine, öz-özünçö, az-az, bala-çaka, amanesen, sak-salamat, küç-kubat, kaada-salt, otuz-kırk, 5-6 kişi, tört-beş, ha-ha-ha, tars-tars, kobursobur (KTCE, s. 8, 13), balt - balt, balt-salt, kez-kezde (KTOS, s. 90, 253).

Kumuk Türkçesi: xinti - minti, bir - birine, butağı - zatı, oñmay - ösmey, oñup - ösüp, ata - baba (ÇTYD3, s. 521, 522, 529).

Özbek Türkçesi: åmmäviy - siyåsiy, åtä - ånä, däråmäd - pul, ketmä - ket (ÇTYD2, s. $85,86,89)$.

Nogay Türkçesi: esitkenin - körgenin, terlep - terşip, ata - ana (ÇTYD3, s. 337, 344), xatın - q1zlar, yas - yawqa, tüslerine - zatına, erte - erte, türli - türli, uq - uq, özi - özi, qurt qumırsqalar, bir - eki (ÇTLMA, s. 516, 521, 523, 526, 530, 532).

Tatar Türkçesi: bela - kazasız, sav - selamet, tanış - bĭlǐşlerge, etkem - enkem (ÇTYD3, s. 73, 76), qoort - qort, cilpiy - cilpiy, pi - pi, qağına - qağına, bäynä - bäynä, ikěşär - öçär, ikĕ - öç, běr - ikě (ÇTLMA, s. 341, 342, 358, 400, 401). $65)$.

Tuva Türkçesi: hölbeñ - hölbeñ, tep - tep, hap - hap, ak - kızıl, uş - baş (BN, s. 29, 30,

Türkmen Türkçesi: ayr1-ayrı (TD, s. 3), biri-birinden, fonetika-grammatiki (TD, s. 5), hatl1-savatl1 (TD, s. 7).

Yakut Türkçesi: körüüte - xarayı1ta (bakım özen), ustata - tuorata (ucu bucağı), kuoyanı - mañkını (kasnağını sırığını) (ÇTLMA, s. 578, 579, 581).

\subsection{Nokta Kullanımı}

Türkiye Türkçesinde yüzyıl ifade ederken sıra sayıları rakamla gösterildiğinde rakamdan sonra bir nokta konur ya da rakamdan sonra kesme işareti konularak derece gösteren ek yazılır: XX. yüzy1l, XV. yüzyıl, XII - XIV. yüzy1llar (YK, s. 12, 27).

Rusçada ise yüzyıl ifade ederken rakamlarında sonra sıra sayı sıfatı için bir işaret kullanılmaz: X - XII vv., XVI v., XVII v. (SRO, s. 5)

Çağdaş Türk lehçelerinde de Rusça yazım kuralının devam ettiği görülür:

Başkurt Türkçesi: 1752 yıldın 16 iyunǐnde, XXIII xalıq - ara (ÇTYD3, s. 275, 278).

Kazak Türkçesi: IX - X sınıptı, XIX ğasırdağı (KTTD, s. 3, 4). 
Kırgız Türkçesi: XIX kılımdagı, XVI-XVII kılımdardagı (KTCE, s. 13).

Özbek Türkçesi: XII asrning (ÇTYD2, s. 89).

Tatar Türkçesi: IX gasır, X gasırga (ÇTYD3, s. 79).

Türkmen Türkçesi: XIX asır (TD, s. 6).

\subsection{Tire Kullanımı}

2.4.1. Türkiye Türkçesinde sıra sayıları rakamla gösterildiğinde rakamdan sonra bir nokta konur ya da rakamdan sonra kesme işareti konularak derece gösteren ek yazılır: 15., 56., XX., 15'inci, 56'inc1, XX'inci (YK, s. 12) vb.

Rusçada ise sıra sayı sıfatlarını belirtmek için +InçI, +UnçU eki yerine tire kullanılır: 5go, 20-y (PROP, s. 112) vb.

Çağdaş Türk lehçelerinde de Rusça yazım kuralının devam ettiği görülür:

Altay Türkçesi: 2-çi (AVAY, s. 106).

Azerbaycan Türkçesi: 6-c1, 2-ci, 10-cu, 3-cü (ADOQ, s. 6), 1949-cu, 1950-ci, 1926-c1, 1955-ci (ADE, s. 5).

Gagavuz Türkçesi: 20 - inci, II - nci hem III - üncü, 10 - uncu (GDL, s. 19, 22, 57).

Karakalpak Türkçesi: 1938-44 - j1lları, 1948 - j111, 1949 - j111 (ÇTYD3, s. 462).

Kazak Türkçesi: 7-nşi sınıp, 15-inşi üy, 50-inşi kilometr (KTA, s. 53).

Kırgız Türkçesi: 2008-c1l, 16-noyabr, 4-klass, 2-masele (KTCE, s. 13).

Özbek Türkçesi: 35 - qaidaning 2 - bandi, 1991 - yilning (HOAD, s. 110, 112), 1485 1486 - yillarda, 1483 - yilda, 1485 - yilning, 1480 - yillarning, 1488 - yilda, 30 - yillarda, 4 oktabrda (ÇTYD2, s. 89, 91).

Türkmen Türkçesi: 1985-nci (TD, s. 3), 1929 - 1930-1ncı (TD, s. 4), 1905-inci (TD, s. $5)$.

2.4.2. Türkiye Türkçesinde tırnak içinde olmayan alıntı cümlelerden sonra, konuşma çizgisinden sonraki alıntı cümlesinin bitiminde virgül kullanılır:

Adana'ya yarın gideceğim, dedi.

- Bu akşam Datça'ya gidiyor musunuz, diye sordu. (YK, s. 29)

Rusçada ise tırnak içinde olan ya da olmayan alıntı cümlelerden sonra, konuşma çizgisinden sonraki alıntı cümlenin bitiminde (bazen virgülün ardından) tire kullanılır:

- Çto vas privelo k nim? - neojidanno bitovım, vorçlivım golosom sprosil on. (PROP, s.

"Çto on skazal?", - sprosil Anton; "Poedem v gorod", - skazala ona. (RD, s. 256)

Çağdaş Türk lehçelerinde de Rusça yazım kuralının devam ettiği görülür:

Altay Türkçesi: alar kerek - dep, su-kadık bol - dep (ÇTLMA, s. 691, 700).

Azerbaycan Türkçesi: "sevmeyen namerd olur" - cümlesinde (ADST, s. 7), "iş işle" ifadesinde (ADST, s. 9).

Başkurt Türkçesi: eytĕrbĕz, - digender; bal yıyırhııı, - dip (ÇTLMA, s. 466).

Çuvaş Türkçesi: "Ku çǐn kalanǐ ikken", - tese ašnnış (O doğru söylemiş, diye anacaklar) (ÇTLMA, s. 798). 
Gagavuz Türkçesi: Bän şindän sora inanmayacam Topal Şeytanı, - demiş kemençeci (GDL, s. 119).

Hakas Türkçesi: - Udaa sığadırzıñ ma put ağa? - surğan Galya, - Çe oynap alaañ, sölepçe örbekey, - Kolya, ĭdi çarabas, - tǐpçe, Mına minǐñ tetrad'ım, - tĭpçe Kolya (Ç, s. 5, 23, 25). $583,584)$.

Karaçay-Balkar Türkçesi: eşeğim mında coqdu, - deb, berseñ a! - deb (ÇTYD3, s. 582,

Karakalpak Türkçesi: -Gümis öldi - dedi; - Neşege keldin? - dep sorapt1; ... beremen, dep (ÇTYD3, s. 463, 464).

Kazak Türkçesi: Barmısın? - dep, "bolar edi” - dep, avzına suv tamızındar, - deydi (B, s. $4,9,11)$.

Kumuk Türkçesi: buzavğa soq! - dep; “...qoçayıq!” - dey (ÇTYD3, s. 521).

Nogay Türkçesi: ... akaşar ediler. - degen Koca; Aşamagan bolayaksıñ, - dep; nege? dep soraydı (ÇTYD3, s. 337, 338); “... bir az uyqlayım”, - dep; “... oylastım äşe?” - dedi; berermen, - dedi; "adaspañı!" - degendey (ÇTLMA, s. 514, 532).

Özbek Türkçesi: Visshiy klass! - dedi u. (HOAD, s. 6), “... åxiridä xår bolmäysän!” debdi, pul tåtli bolädi, - degän ekän (ÇTYD2, s. 86).

Tatar Türkçesi: elle onıttıñmı? - dip, kırık, - dip cavap birgen (ÇTYD3, s. 66, 83); kittěk, kittěk! - dip, pi-pi - dep, cibörçě, - diylär, -Äydä, - diy, Quyçım, kil bire, - dide (ÇTLMA, s. 341, 358, 359, 401).

Yakut Türkçesi: - Min duo? - dien 1yıtar kini (-Ben mi?, diye sorar o), Uunan,-dien xoruydaabıt balıksıt. (-Su ile, diye cevaplamış balıkçı) (ÇTLMA, s. 578, 581).

2.4.3. Türkiye Türkçesinde yüklemden uzak düşmüş öznelerden sonra virgül kullanılır:

Saniye Hanımefendi, merdivenlerde oğlunun ayak seslerini duyar duymaz, hasretlisini karşılamaya atılan bir genç kadın gibi koltuğundan fırlamış ve ona kapıyı kendi eliyle açmaya gelmişti. (YK, s. 28)

Rusçada ise tanım cümlelerinde, öznelerden sonra tire kullanılır: Moya sestra uçitel'nitsa, a brat - zootehnik; brat - moy uçitel'; ya - uçitel', a tı - injener (PROP, s. 206, 208) vb.

Çağdaş Türk lehçelerinde de Rusça yazım kuralının devam ettiği görülür:

Altay Türkçesi: May-ene - üy ulustıñ ... (ÇTLMA, s. 691, 700), Altay til - altay elconnın töröl tili, "cer cakşızı - sas, er cakşızı suras" (AVAY, s. 96, 104). s. 462).

Başkurt Türkçesi: bürŭ - usal yırtqıs (ÇTYD3, s. 277), Bělĕm yorto - mektep (ÇTLMA,

Gagavuz Türkçesi: Traktor hem kombayn - iki faydalı maşina (GDL, s. 23).

Hakas Türkçesi: Noyabr' - sovet çonınıñ ülükünı̆, pǐstĩñ adıbıs - oktyabryatalar, ürgenı̌s - uluğ toğıs (Ç, s. 25, 29).

Kazak Türkçesi: "Qasekeñ” degen - Qasbolat (B, s. 11), Til - koğamdık kubılıs, jastar bizdiñ bolaşağımız (KTA, s. 70).

Kırgız Türkçesi: Çıñgız Aytmatov - Kırgız el cazuuçusu, bilim - tügönbös baylık (ÇTYD3, s. 221).

Özbek Türkçesi: ilmiy uslub - ilmiy asarlar tilini va ilmiy nutqni qoliplaydi (HOAD, s. 5), birinchi devoni - "Badoye ul-bidoya", mening jonim - omonat jon (ÇTYD2, s. 86). 
Tatar Türkçesi: Törĭk tili - Törkiye cömhuriyetǐnǐn devlet tîlı̆, xuca - osta atuç1 (ÇTYD3, s. 81, 88); bu - älĕ bügĕn irtä gĕnä kilěp töşkän ...(ÇTLMA, s. 401)

Tuva Türkçesi: Ugbam - saançı, Avam, açam - kadarçılar (BN, s. 21, 32).

\subsection{Kısaltmaların Yazımı}

Türkiye Türkçesinde kısaltmalara getirilen ekleri ayırmak için kesme işareti kullanılır: TBMM'nin, TDK'nin, BM'de, ABD'de, TV'ye (YK, s. 40) vb.

Rusçada ise kısaltmalara gelen ekler kesme işaretiyle ayrılmaz ve kısaltmaya bitişik yazılır: raboçie ZILLa, rabotat' v MiDe, p'esa postavlena MHATom (PROP, s. 192) vb.

Kırgız Türkçesinde Rusça yazım kuralının devam ettiği görülür: SSRnin (KTO, s. 8), KUUnun, UAKtın, BUUga, MAİnin, KTRdin, KRdin (KTCE, s. 8). ile ayrilır:

Azerbaycan, Hakas, Kazak ve Türkmen Türkçelerinde ise gelen ekler kısaltmadan tire

Azerbaycan Türkçesi: MEA-dan, BMT-ye, MDB-nin (ADOQ, s. 11), Naxçıvan MSSRin (ADE, s. 32).

Hakas Türkçesi: SSSR-niñ paza VKP-nıñ (PUS, s. 14).

Kazak Türkçesi: KR UĞA-nın (KTTD, s. 3), TÜE-ge (AVAY, s. 105), AKŞ-ka, BAMğa, YUNESKO-nın, MTZ-82-ge, km-den, cm-ge (KTA, s. 35, 36).

Türkmen Türkçesi: TSSR IA-nın (TD, s. 3).

\section{6. Özel İsimlere Gelen Eklerin Yazımı}

Türkiye Türkçesinde özel isimlere gelen iyelik, durum veya bildirme ekleri kesme işaretiyle ayrılır: Kurtuluş Savaşı'nı, Atatürk'üm, Türkiye'mizin, Fatih Sultan Mehmet'e, Yunus Emre'yi, Ziya Gökalp'tan, Refik Halit Karay'mış, Ahmet Cevat Emre'dir, Namık Kemal'se, Şinasi'yle, Alman'sınız, Kırgız'ım, Karakeçili'nin, Osmanlı Devleti'ndeki, Cebrail'den, Çanakkale Boğazı'nın, Sait Halim Paşa Yalısı'ndan, Resmî Gazete'de, Millî Eğitim Temel Kanunu'na, Telif Hakkı Yayın ve Satış Yönetmeliği'ni, Eski Çağ’ın, Yükselme Dönemi'nin, Cumhuriyet Dönemi Türk Edebiyatı'na (YK, s. 38-39) vb. 131).

Rusçada ise özel isimlere gelen ekler kesme işaretiyle ayrılmaz: Gagarinımi (OP, s.

Çağdaş Türk lehçelerinde de Rusça yazım kuralının devam ettiği ve bu nedenle özel isimlere gelen iyelik, durum veya bildirme eklerinin kesme işaretiyle ayrılmadığı görülür:

Altay Türkçesi: Ceti - Sarıga, Cakşılaydıñ, Kara-Çoltorgo, Kara-Suuda, Orto Aziyanıñ, Sibirdiñ (ÇTLMA, s. 696, 706, 710, 712), Surazakovtın, Mihaylovnanı̃̃ (AVAY, s. 98, 101).

Azerbaycan Türkçesi: Bakıda, Şuşadan (ADE, s. 5), T. Hacıyevin, B. Sadıkovun (ADE, s. 7), Azerbaycan Dövlet Universitetinde (ADE, s. 17).

Başkurt Türkçesi: Başqortostandan, Başqortostandıñ, Volganıñ (ÇTYD3, s. 273, 275, 276).

Gagavuz Türkçesi: Devlet Universitetini, Komrada, Todur Marinoglunun (GDL, s. 208).

Hakas Türkçesi: Hakasiyanıñ (PUS, s. 4), Leningradta, Leninniñ (Ç, s. 23).

Karaçay-Balkar Türkçesi: Türkde, Nasra Xocanı, Orta Aziyada, Yerivanda, Dağıstanda (ÇTYD3, s. 588, 589).

Karakalpak Türkçesi: Taşkentte, Q. Täjibayevtan, Nökiste, A. Qädiridiñ, Ömirbektin (ÇTYD3, s. 462, 463). 
Kazak Türkçesi: Til bilimi institutınıñ, Memlekettik emtixan komissiyasınıñ, Kazakstan Respublikası joğarı attestatsiyalık komissiyasınıñ, İ. A. Batmanovtıñ, B. Äbilkasımulınıñ, V. V. Radlovdun (KTTD, s. 3, 6, 7).

Kırgız Türkçesi: Orozovdun, Orozovdu, Orozovdo, Orozovdon (NOKY, s. 7).

Nogay Türkçesi: Yolavşıdı, Hannıñ, Yolavşıdıñ, Tahirge (ÇTYD3, s. 339, 342); Y. L. Nemirovskiydiñ, Qoreyadıñ, Qoreyadan, Yaponiyağa, Qıtaylardan, Ninadıñ (ÇTLMA, s. 523, 532).

Özbek Türkçesi: O‘zbekistonning, O‘zbekistan Respublikasining (HOAD, s. 8), Özbekiståndägi, Shoh Husayn Bayqaroning, Alisher Navoiyning, Moskvaga, Toshkentga, Cho'lponni (ÇTYD2, s. 85, 89, 91).

Tatar Türkçesi: Zöhrägä, Arıslanbaynıñ, Sarsımbaynıñ, Sasnağa, Qazanğa, Qazannan (ÇTLMA, s. 360, 401, 419, 420).

Türkmen Türkçesi: Amanmırat Annanurovın, P. Azımovın (TD, s. 3).

Yakut Türkçesi: Uohugu (< Uohuk) (ÇTLMA, s. 593).

\subsection{Diğer Farklılıklar}

Rusça imlâ kuralları etkisi elbette ki yukarıdaki tespitler ile sınırlı değildir. Bunların dışında da bazı kullanımlarda Rusça imlânın etkisi vardır:

Türkiye Türkçesinde özel adlardan türetilen ve kişinin nereli olduğunu belirten kelimeler büyük harfle başlar: Konyalı, Bursalı (YK, s. 17). Rusçada ise kişinin nereli olduğunu belirten kelimeler küçük harfle başlar: almaatintsı, kostarikants1, losandcelests1 (PROP, s. 122). Kırgız Türkçesinde de yer adlarından türetilen ve kişinin nereli olduğunu belirten kelimeler küçük harfle başlar: alaylık, kaşkarlık, 1sık-köldük, narındık (KTCE, s. 10).

Türkiye Türkçesinde sayılara getirilen ekler kesme işaretiyle ayrılır: 1985'te, 8'inci madde, 7,65'lik, 657'yle (YK, s. 40). Rusçada ise sayılara ek gelirken araya tire konur: 2-go, 1go, 3-go (PROP, s. 40, 80). Azerbaycan Türkçesinde ise sayılardan sonra isim çekim ekleri gelirken araya tire konur: 20-den, 3-de, 2-ye, 6-nın, 5-i, 17-si (ADOQ, s. 6).

Türkiye Türkçesinde meslek, unvan bildiren sözcükler bitişik ve ayrı yazılabilirler: yardımcı doçent, yardımcı hakem, başhekim, başhemşire, genel başkan (YK, s. 131, 256, 560). Rusçada ise meslek, unvan bildiren birleşik sözcüklerin arasında tire kullanılır: vitse-prezident, general-gubernator, privat-dotsent (PROP, s. 125-126). Kırgız Türkçesinde de Rusça yazım kuralının devam ettiği görülür: müçö-korrespondent, zootehnik-selektsioner, mehanizatoraydooçu, akın-dramaturg, vraç-terapevt, prem'er-ministr, general-leytenant (KTCE, s. 13).

Türkiye Türkçesinde sözcüklerin ilk ve son harfleriyle kısaltma yapılmadığı için tire işareti kullanılmamaktadır (YK, s. 41-42). Rusçada ise sözcüğün ilk ve son hece ya da harfi ile yapılan kısaltmaların arasında kısa çizgi kullanılır: d-r (doktor), b-ka (biblioteka "kütüphane") (PROP, s. 111). Azerbaycan Türkçesinde de Rusça biçim korunmaktadır: d-r, z-d (zavod) (ADOQ, s. 11) vb.

\section{Rusça İmlâ Kuralları Etkisinin Olmadığı Farklılıklar}

Türkçenin dil bilgisine özgü olan soru eki ve "DA" bağlacının yazımı da çağdaş Türk lehçelerinde farklılık gösterebilmektedir:

\subsection{Soru Ekinin Yazımı}

Türkiye Türkçesinde soru eki, kendisinden önceki kelimenin son ünlüsüne bağlı olarak ünlü uyumlarına uyar ve ayrı yazılır: Kaldı mı?, Sen de mi geldin?, Olur mu? (YK, s. 9).

Altay, Gagavuz, Hakas, Karakalpak, Kazak ve Tuva Türkçelerinde soru eki Türkiye Türkçesindeki gibi ayrı yazılmaktadır: 
Altay Türkçesi: kirdi be?, tiydi be? (ÇTLMA, s. 696).

Gagavuz Türkçesi: esaplayabilecek mi bu davayı?, sän vardır mı gördüün sabaa yıldızını?, bu su tat1ı mı? (GDL, s. 109, 114).

Hakas Türkçesi: pĭlçezer be?, Tashıl ba?, udaa sığadırzıñ ma? (Ç, s. 4, 5).

Karakalpak Türkçesi: şıkpaysañ ba? (ÇTYD3, s. 463).

Kazak Türkçesi: barasıñ ba?, kelesiñ be? (KTA, s. 37), qondı ma?, bar ma?, bir nerse sıkırlay ma?, kekşil degen emes pe, kelesiñ be? (B, s. 6, 9, 35).

Tuva Türkçesi: çanında malçın olur be?, bilir siler be?, bolur sen be? (BN, s. 20, 23, 49).

Azerbaycan, Başkurt, Karaçay-Balkar, Kumuk, Nogay, Tatar ve Türkmen Türkçelerinde ise " $\mathrm{mI}, \mathrm{mU}$ " soru eki bitişik yazılır:

Azerbaycan Türkçesi: kitabdırmı?, oxudunmu? (ADOQ, s. 8), Özbek Türkçesi: Äbdullämisän?, biläsänmi? (ÇTLMA, s. 111, 112).

Başkurt Türkçesi: bǐlehĭgĭzmĭ? (ÇTYD3, s. 275).

Karaçay-Balkar Türkçesi: telimi?, cırlaymı? (ÇTYD3, s. 585, 587).

Kumuk Türkçesi: bilmeymisen?, barmı? (ÇTYD3, s. 524).

Nogay Türkçesi: barma, yokpa?, esitesiñme? - dep (ÇTYD3, s. 337, 338).

Tatar Türkçesi: elle onıttıñmı?, yaxşımı?, savlarmı?, kildǐmı̌?, barmı? (ÇTYD3, s. 66, $72,73,75)$.

Türkmen Türkçesi: söyyärmisin?, (ÇTLMA, s. 77).

\section{2. "DA" Bağlacının Yazımı}

Bu bağlacın çağdaş Türk lehçelerindeki yazımı büyük oranda Türkiye Türkçesindeki gibidir. Türkiye Türkçesinde bağlaç olan "dA", kendisinden önceki kelimenin son ünlüsüne bağlı olarak ünlü uyumlarına uyar ve ayrı yazılır: Kızı da geldi gelini de., Durumu oğluna da bildirdi., Sen de mi kardeşim?, Güç de olsa., Konuşur da konuşur. (YK, s. 10).

Altay, Başkurt, Çuvaş, Gagavuz, Hakas, Karaçay-Balkar, Karakalpak, Kazak, Kumuk, Nogay ve Tatar Türkçelerinde de Türkiye Türkçesindeki gibi “da” bağlacı ayrı yazılır:

Altay Türkçesi: kayda da bolza (ÇTLMA, s. 705), kuuçındaar da (AVAY, s. 96).

Başkurt Türkçesi: Pugaçyovsılarzan da (ÇTYD3, s. 276), ożon da, yönteś te, uylagan da, ulay ża (ÇTLMA, s. 465).

Çuvaş Türkçesi: Çĩvaş çmlhi te (ÇTLMA, s. 797).

Gagavuz Türkçesi: okadar da, Gagarin dä Titov da, dokuz da kızı (GDL, s. 11, 23, 24).

Hakas Türkçesi: agastar daa taglar daa (PUS, s. 9), halas taa, suhar' daa, sin dee, ağas taa, tökpes tee (Ç, s. 26, 58).

Karaçay-Balkar Türkçesi: kesi da, inanmaysa da, bar edi da, sen da, degendile da, aman da, igi da (ÇTYD3, s. 583, 584, 586, 587).

Karakalpak Türkçesi: şet ellerde de, bolsa da, kelse de, bügin de (ÇTYD3, s. 463).

Kazak Türkçesi: niyeti buzılsa da, bolsa da, eki jağının da, jaqta da (B, s. 3, 4, 9), baska da (KTTD, s. 4).

Kumuk Türkçesi: bir buzavu da bir qozusu da, onu da, teri de, salam da, toğuz da, qatını da (ÇTYD3, s. 526). 
Nogay Türkçesi: xatını da, bolsa da, solay da (ÇTYD3, s. 338, 339); ädet bayramı da, ol da, kartı da, yası da, özine de, ädem de, zatqa da (ÇTLMA, s. 516, 521, 530).

Tatar Türkçesi: kiyı̌ndǐ de (ÇTYD3, s. 67), Zöhrä dä, bu da, kitä dä, yözně dä (ÇTLMA, s. $358,361,418)$.

Ancak Özbek, Tuva ve Türkmen Türkçelerinde ise sözcük ile "da" bağlacı arasına kısa çizgi konulur:

Özbek Türkçesi: qaräbdi - da, bo'lsa - da, bizdan - da, aydan - da, ul - da, kundan - da (ÇTYD2, s. 86, 90, 91, 92).

Tuva Türkçesi: maa börü-daa, adıg-daa, sıın-da çoruur, hölçok-daa, kım-daa, dilgi-daa (BN, s. 20, 65, 66).

Türkmen Türkçesi: başga-da (TD, s. 3), hem-de, bolsa-da (TD, s. 5), ayratın-da (TD, s. 7).

\section{Sonuç}

Farklı tarihli ve farklı alfabelerle yazılmış kaynaklardan yapılan tespitlere göre, Türk dünyasında ortak yazı dili ve alfabe yanında ortak imlâ (yazım) kurallarının da belirlenmesi gerektiği görülmüştür. 1956 yılında şekillendirilen Rusçanın imlâ (yazım) kuralları, Sovyet yönetimi altında kalmış olan tüm Türk lehçelerinin yazımına yansıdığı için bu lehçelerde neredeyse ortak bir imlânın (yazım) kullanıldığı görülmektedir. Bu ortak imlânın (yazım) nedeni, yazı dilleri oluşturulurken Kiril alfabesi yanında Rusçanın imlâsının da dayatılmış olmasıdır. Bu ortak imlânın (yazım) günümüze kadar sürmesinin nedeni ise Rusçanın ve de Kiril alfabesinin uzun süre kullanılmış olmasıdır. Öyle ki Azerbaycan, Türkmenistan ve Özbekistan Latin alfabesine geçmelerine rağmen aynı imlâ (yazım) kurallarını yine devam ettirmektedirler. Bu sebeplerle Türkiye Türkçesinin imlâ (yazım) kuralları ile Sovyet yönetimi altında kalmış olan tüm Türk lehçelerinin imlâ (yazım) kuralları büyük farklılık göstermektedir.

Rusça imlâ kuralları etkisi elbette ki yukarıdaki tespitler ile sınırlı değildir. İmlâ kurallarının tamamı karşılaştırıldığında yine bazı farklılıklar mutlaka ortaya çıkacaktır. Bu farklılıklar büyük oranda Rusça imlâ kurallarının etkisiyle olmuştur. Ancak Rusça imlâ kuralları etkisinin olmadığı farklı imlâ (yazım) kuralları da vardır. Bunlar arasında soru eki kullanımında farklılıkların daha çok olduğu, "DA" bağlacı kullanımında ise büyük oranda birliktelik sağlandiğı görülmektedir.

Türk dünyasının dilde birlikteliği açısından ortak imlâ (yazım) kuralları önemlidir. Bunun için ortak Latin alfabesi ile birlikte Türkçenin yapısının ve kurallarının göz önünde bulundurulduğu ortak imlâ (yazım) kurallarının belirlenmesi ve belirlenen kuralların yazılı ve görsel ortamlarda uygulanması gerekmektedir. Bunun için Türk dünyası ortak imlâ (yazım) komisyonu oluşturulmalı ve alınan kararların devlet organları vasıtasıyla uygulanması ve yaygınlaştırılması sağlanmalıdır. 


\section{Kaynaklar ve Kisaltmalar}

ABDİEVA, R. (2017). Bağımsızlıklarını Kazandıktan Sonra Türk Cumhuriyetlerinin Dil Politikaları ve Türkiye İle Ortak Dil ve Ortak Alfabe Çalışmaları. Uluslararası Türk Lehçe Araştırmaları Dergisi (TÜRKLAD). C. 1, S. 2, s. 104-119.

ADİLOV, M. (1974). Azerbaycan dilinde sintaktik tekrarlar. Bak1: Elm neşriyyat1.

Aktual'nıe Voprosi Altayskogo Yazıkoznaniya: Problemı Razvitiya Literaturnogo Yazıka, Soverşenstvovanie Sovremennoy Orfografii. Red.: M. S. Dedina, N. V. Ekeev, A. N. Mayzina, A. E. Çumakaev (sor. red.). Pravitel'stvo Respubliki Altay Ministerstvo Obrazovaniya i Nauki Respubliki Altay. Gorno-Altaysk 2017.

ALDIN-OOL, A. A. (2010). Bodun Nomçu. Kız1l.

ATMACA, E. (2012). Kazak Türkçesinin Söz Varlığındaki Rusça Alıntılar ve Ses Değişmeleri. Turkish Studies. Vol. 7/3, p. 275 - 298.

AXTANOV, T. (2002). Boran. Almatı: Jazuvş1.

BABOGLU, İ. İ.; Baboglu, N. İ.; VASILİGLU, K. K. (2003). Gagauz Dili hem Literatura. Ştiinta.

BAKEEV, K.; BATMANOV, İ.;BAKTIBAEV, U. (1938). Novaya Orfografiya Kirgizskogo Yazıka., Frunze: Kırgızmambas.

BULUT, M. (2013). Cumhuriyet Dönemi’nden Günümüze Yapılan Türkçe Yazım Kılavuzu Çalışmaları ve Türkçe Yazım Kılavuzları Üzerine Bir Kaynakça Denemesi. The Journal Of Academic Social Science Studies (JASSS). V. 6, I. 6, p. 277-304.

BURAN, A.; ALKAYA, E. (2014). Çağdaş Türk Yazı Dilleri - 2. Ankara: Akçağ Yay.

BURAN, A.; ALKAYA, E. (2014). Çağdaş Türk Yazı Dilleri - 3. Ankara: Akçağ Yay.

BURAN, A. (2009). Sovyet Türkolojisi ve Birinci Türkoloji Kurultayı. Turkish Studies, C. $4 / 3$, s. $430-444$.

Çağdaş Türk Lehçeleri - Metin Aktarmaları. (Ed. Nergis BİRAY), İstanbul: Kesit Yayınları, 2016.

DİETRİCH, A. P. (2004). Rusça Dilbilgisi. İstanbul: Multilingual Yay.

DOMOCAKOV, N. G. (1948). Orfografiçeskay Slovar'. Abakan: Hakoblnatsizdat.

ELEKBERLİ, N. (2010). Azerbaycan dilinin orfoqrafiya qaydalart. Bak1.

JAMOLXONOV, H. (2005). Hozirgi O'zbek Adabiy Tili. Toshkent: Talqin.

KARASAEV, H.; YANŞANSİN, Yu. (1947). Kırgız Tilinin Orfografiyası. SSSR İlimler Akademiyasının Kırgız Filialı; Til, Adabiyat cana Tarih İnstitutu. Frunze.

KARASAEV, H. K. (2009). Kırgız Tilinin Orfografiyalık Sözdügü. Bişkek.

KAYDALOVA, A. N. - KALININA, N. K. (1983). Sovremennaya Russkaya Orfografiya. Moskva.

KAZANAKOV, A. T. (1940). Pravopisaniyedeñer Uprajneniyelerdiñ Sbornigi, III Çardıg1, Hakoblnatsizdat, Abakan.

Kırgız Tilinin Cazuu Ereceleri. Kırgız Respublikasının Prezidentine Karaştuu Mamlekettik Til Boyunça Uluttuk Komissiyasının Aldındagı Okuu-Maalımat Borboru. Bişkek 2013.

LOPATiN, V. V. (2007). Pravila Russkoy Orfografii $i$ Punktuatsii. Moskva: İzdatel'stvo "EKSMO". 
MUHIEV, H. - Kürenov, S. (1988). Türkmen Dilçileri. Aşgabat: Magarıf.

NURİAHMETOVA, A. (2014). Günümüz Kırgız Türkçesinde Rusça Unsurlar. The Journal Of Academic Social Science Studies (JASSS). Number 27, Autumn I 2014, p. 333 - 347.

ÖZEREN, M. (2010). Kırgız Türkçesindeki Rusça Alıntı Sözcükler ve Bu Sözcüklerdeki Ünsüz Olayları. Zeitschrift für die Welt der Türken Journal of World of Turks. Vol. 2, No. 2 (2010), s. 227-241.

Qazaq Tili Tarixı men Dialektologiyası. (Red. Ö. Aytbayulı, B. Momınova). Almatı: Ar1s baspas1, 2001.

SAGALAKOVA, E. M. - KAZAÇINNOVA, G. G. - TYUTYUBEEVA, A. N. (1991). Çıltızah. Hakasskoe otdelenie Krasnoyarskogo knijnogo izdatel'stva. Abakan.

$$
\text { Sizdı, } \quad \text { R., Kazak Tilinin Anıktağışı }
$$
(http://emle.kz/uploads/files/b075e9dd7588af946e376c24993e166a.pdf (02.11.2018))

ŞANSKIY, N. M. - İvanov, V. V. (1987). Sovremennıy Russkiy Yazık. Moskva.

ŞİRELIYEV, M. (2008). Azerbaycan Dialektologiyasının Esaslart. Bakı: Şerq-Qerb. Prosveşçenie.

UŞAKOV, D . N. - KRYUÇKOV, S. E. (1974). Orfografiçeskiy Slovar'. Moskva: Neolit.

VALGINA, N. S. - SVETLIŞEVA, V. N. (2001). Orfografiya i Punktuatsiya. Moskva:

Voprosı Soverşenstvovaniya Alfavitov Tyurkskih Yazıkov SSSR. (Ot. Red.: N. A. Baskakov) Moskva: İzdatel'stvo "Nauka”. 1972.

Yazım Kılavuzu. Ankara: Türk Dil Kurumu Yayınları. 2012.

http://anasozu.com/gagauz-kulturasinin-altin-fondun-bilim-kiyatlarina-kdudaprezentatiya/ (01.11.2018)

http://www.tdk.gov.tr/index.php?option=com_bts\&arama=kelime\&guid=TDK.GTS.5bc 09f7e8c6fb3.18821964 (12.10.2018)

https://24.kz/ru/news/obrazovanie-i-nauka/item/205065-spetsialisty-pristupili-krazrabotke-novykh-pravil-kazakhskoj-orfografii (26.10.2018)

https://www.gorno-altaisk.info/news/18490 (26.10.2018)

https://www.zakon.kz/4887490-posle-perehoda-na-latinitsu-pravila.html (26.10.2018) $(26.10 .2018)$

https://www.zakon.kz/4934407-u-novoy-orfografii-kazahskogo-yazyka.html 